\title{
Investigations of copper(II) complexation by fragments of the FBP28 protein using isothermal titration (ITC) and differential scanning calorimetry (DSC)
}

\author{
Joanna Makowska ${ }^{1}$ Dariusz Wyrzykowski ${ }^{1}$ - Paulina Hirniak ${ }^{1}$ - Dorota Uber $^{1}$ • \\ Lech Chmurzyński ${ }^{1}$
}

Received: 18 September 2014/ Accepted: 18 March 2015/Published online: 4 April 2015

(C) The Author(s) 2015. This article is published with open access at Springerlink.com

\begin{abstract}
Isothermal titration calorimetry (ITC) was used to study the interactions between copper(II) ions and peptides with sequences taken from the N-terminal loop of the FBP28 protein (formin-binding protein) WW domain: AcLys-Thr-Ala-Asp-Gly-Lys-Thr-NH ${ }_{2}$ (D7) and Ac-Tyr-LysThr-Ala-Asn-Gly-Lys-Thr-Tyr- $\mathrm{NH}_{2}$ (D9 M), respectively. Measurements were taken at $298.15 \mathrm{~K}$ in $20 \mathrm{mM} 2-(\mathrm{N}-$ morpholino)ethanesulfonic acid buffer solution at a $\mathrm{pH}$ of 6. The stoichiometry, conditional stability constants and thermodynamic parameters $\left(\Delta_{\mathrm{ITC}} G, \Delta_{\mathrm{ITC}} H\right.$ and $\left.\Delta_{\mathrm{ITC}} S\right)$ for the pertinent complexation reactions were determined. Furthermore, the thermal stability of peptide conformations in the presence and absence of copper(II) in the system was investigated using differential scanning calorimetry. Finally, a general procedure on how to include the effect of buffer competition with the peptide for the metal as well as proton competition with the metal for the peptide and the buffer's component during ITC data analysis is described.
\end{abstract}

Keywords FBP28 protein fragments - Metal-peptide binding $\cdot$ ITC $\cdot$ DSC

\section{Introduction}

Peptides have been known to act as chelating agents. Their complex-forming capacity has been utilized in medicine for the treatment of Wilson's disease, for the removal of excess of copper from the liver, and in the prevention of its

Joanna Makowska

joanna.makowska@ug.edu.pl

1 Faculty of Chemistry, University of Gdańsk, ul. Wita Stwosza 63, 80-308 Gdańsk, Poland accumulation [1-7]. In this paper, we present the affinities of two peptides derived from the N-terminal part of the FBP28 protein (PDB code: 1E0L) to copper $\left(\mathrm{Cu}^{2+}\right)$. In particular, the two peptide sequences examined were as follows: Lys-Thr-Ala-Asp-Gly-Lys-Thr-NH 2 (1E0L 12-18, hereafter referred to as D7) and Tyr-Lys-Thr-Ala-Asn-GlyLys-Thr-Tyr-NH $\mathrm{NH}_{2}$ (1E0L 11-19 with the replacement of residue Asp15 with Asn, hereafter referred to as D9 M) (Fig. 1).

The $\beta$-hairpin from the FBP28 protein is known to initiate the folding of this protein [8]. This is an independently forming region whose folding is not induced by a $\beta$-hairpin and is consequently an excellent object by which to study the factors that influence $\beta$-hairpin formation. Results from our preliminary conformational studies of two original fragments of the N-terminal part of the FBP28 protein (1E0L: $12-18$ D7 and the 1E0L: 11-19; the D9 $\mathrm{M}$ is a point mutation of the sequence) [9] fragments suggest that these peptides do not form stable three-dimensional structures in solution (water). However, it was found that D7 forms a large fraction of bent conformations. The $\beta$-hairpin from the FBP28 WW domain has two charged (lysine) residues on opposite strands. According to our previous research [10], these residues, in addition to the charged aspartic acid group that is located in the central part of the sequence, may stabilize the shape of the structure. In order to measure the affinity of the D7 peptide to the $\mathrm{Cu}^{2+}$ ion, a longer (9 residues) peptide fragment from FBP28 (1E0L 11-19) was selected. Simultaneously, within this 9-residue stretch, residue Asp15 was replaced by Asn(D9 M). The effect of elongating the peptide chain with side chains that bear expanded side chains (tyrosines) on the binding properties of the D7 peptide was investigated.

So far, there has been no knowledge concerning the interaction of peptides derived from the FBP28 protein 
Fig. 1 Structure of the 1E0L domain of the FBP28 protein; the marked fragment and its mutant were synthesized and examined

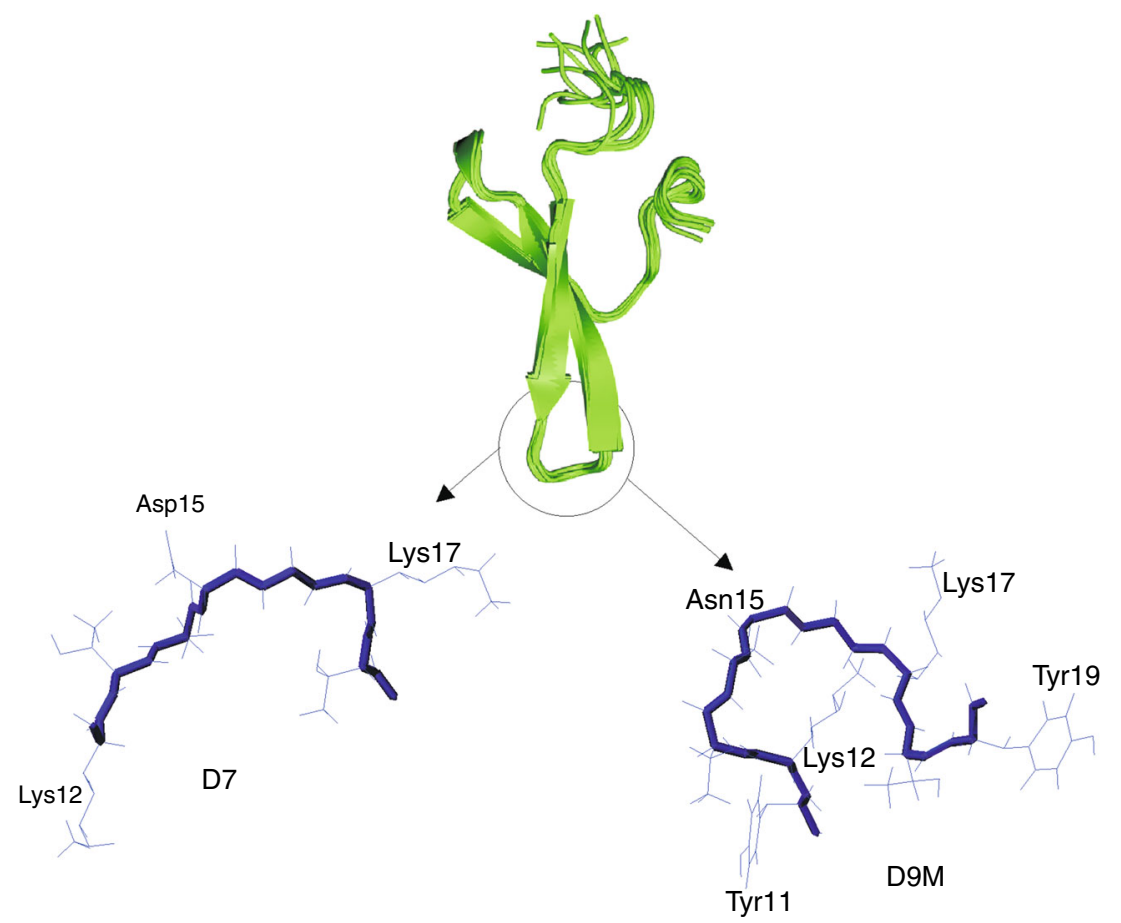

with metal ions. As such, research on this issue is of significant interest.

\section{Materials and methods}

\section{Peptide synthesis}

All peptides under study were synthesized by using the procedure described in our earlier work [11]. The purities of the peptides were 99.98 and $99.99 \%$ for D7 and D9 M, respectively, as assessed by analytical HPLC and MALDITOF analyses.

\section{Isothermal titration calorimetry (ITC)}

All ITC experiments were performed at $298.15 \mathrm{~K}$ using an AutoITC isothermal titration calorimeter (MicroCal Inc. GE Healthcare, Northampton, USA) with a $1.4491 \mathrm{~mL}$ sample and reference cells. The reference cells contained distilled water. All details concerning measuring devices and the experimental setup were described previously $[12,13]$. All reagents were dissolved directly in a $20 \mathrm{mM}$ buffer solution of MES. The $\mathrm{pH}$ of the buffer solution was adjusted to 6.0 with $0.1 \mathrm{M} \mathrm{HClO}_{4}$. The experiment consisted of injecting a $10.02 \mu \mathrm{L}$ (29 injections, $2 \mu \mathrm{L}$ for the first injection only) buffered solution of $\mathrm{Cu} 2+(\mathrm{ca} 2 \mathrm{mM}$ ) into the reaction cell, which initially contained a ca $0.25-0.5 \mathrm{mM}$ buffered solution of peptide. A background titration, consisting of an identical titrant solution, but with buffer solution in the reaction cell only, was removed from each experimental titration to account for the heat of dilution. All the solutions were degassed prior to titration. The titrant was injected at 5-min intervals to ensure that the titration peak returned to the baseline before the next injection. Each injection lasted $20 \mathrm{~s}$. For the sake of homogeneous mixing in the cell, the stirrer speed was kept constant at $300 \mathrm{rpm}$. A calibration of the AutoITC calorimeter was carried out electrically by using electrically generated heat pulses. A $\mathrm{CaCl}_{2}$-EDTA titration was performed to check the apparatus, and the results $(n-\mathrm{s}-$ toichiometry, $K, \Delta H$ ) were compared with those obtained using a test kit from MicroCal Inc. GE Healthcare.

\section{Differential scanning calorimetry (DSC)}

Calorimetric measurements were taken with a VP-DSC microcalorimeter (MicroCal) at a scanning rate $90{ }^{\circ} \mathrm{C} / 1 \mathrm{~h}$. Scans were obtained at a protein concentration of $\mathrm{c} \sim 0181$ and $\mathrm{c} \sim 0165 \mathrm{mM}$ for D7 and D9 M, respectively. The cell volume was $0.5 \mathrm{~mL}$. All scans were run at pH 6.5 in MES buffer, in a temperature range from 5 to $90{ }^{\circ} \mathrm{C}$. The reversibility of the transition was checked by cooling and reheating the same sample. These measurements were recorded three times. Results from DSC measurements were analyzed using the software Origin 7.0 from MicroCal, employing routines included with the instrument [14]. 


\section{Results and discussion}

The conditional parameters were obtained directly from the ITC experiment by fitting binding isotherms, using nonlinear least-square procedures, to a model that assume a single set of identical binding sites. The representative binding isotherms for the $\mathrm{Cu}^{2+}-\mathrm{D} 7$ and $\mathrm{Cu}^{2+}-\mathrm{D} 9 \mathrm{M}$ interactions in MES buffer are shown in Fig. 2, whereas conditional thermodynamic parameters of the interactions are summarized in Table 1. Based on the ITC measurements, it has been found that the stoichiometry $\mathrm{N}$ ( $\mathrm{N}=$ [metal ion]/[peptide]) of the complexes is equal to 3:2 and $1: 1$ for $\mathrm{Cu}-\mathrm{D} 7$ and $\mathrm{Cu}-\mathrm{D} 9 \mathrm{M}$, respectively. The positive values of the enthalpy of the complexation reaction indicate that the positive endothermic effects connected with dehydration of both the copper(II) ion and the peptide (on account of the change in peptide conformation) are not overcompensated by an exothermic effect due to the formation of new $\mathrm{Cu}$-peptide bonds (Table 1). Thus, the thermodynamic stability of the complexes studied strongly depends on the entropy change. The higher positive value of $\Delta H$ for the $\mathrm{Cu}^{2+}-\mathrm{D} 9 \mathrm{M}$ complex can suggest lesser covalent character of the $\mathrm{Cu}^{2+}-\mathrm{D} 9 \mathrm{M}$ interactions than in the case of the $\mathrm{Cu}^{2+}-\mathrm{D} 7$ ones, as well as a more effective solvation process for the $\mathrm{D} 9 \mathrm{M}$ peptide.

The conditional (observed) $\mathrm{Cu}$ (II)-peptide binding constant $\left(K_{\text {ITC }}\right)$, obtained directly from the ITC experiment, is conditioned by buffer (MES) competition with the peptide for the copper(II) ion, as well as proton
Table 1 Conditional thermodynamic parameters of copper(II) binding to D7 and D9 $\mathrm{M}$ in $20 \mathrm{mM}$ MES buffer of $\mathrm{pH}$ of 6 , at $298.15 \mathrm{~K}$

\begin{tabular}{|c|c|c|}
\hline Parameter & D7 & D9 M \\
\hline $\mathrm{N}\left(\mathrm{Cu}^{2+}\right.$ :peptide molar ratio $)$ & $1.55( \pm 0.04)$ & $0.97( \pm 0.04)$ \\
\hline $\log K_{\mathrm{ITC}}$ & $4.68( \pm 0.04)$ & $3.89( \pm 0.03)$ \\
\hline$\Delta_{\mathrm{ITC}} H / \mathrm{kcal} \mathrm{mol}^{-1}$ & $2.18( \pm 0.07)$ & $4.36( \pm 0.40)$ \\
\hline$\Delta_{\mathrm{ITC}} S / \mathrm{cal} \mathrm{mol}^{-1} \mathrm{~K}^{-1}$ & 28.7 & 32.4 \\
\hline$\Delta_{\mathrm{ITC}} G / \mathrm{kcal} \mathrm{mol}^{-1}$ & $-26.73( \pm 0.31)$ & $-22.21( \pm 0.19)$ \\
\hline
\end{tabular}

competition with the copper(II) ion for the buffer and peptide; it is quantified by Eq. (1):

$K_{\text {ITC }}=\frac{K}{\alpha_{\text {proton }} \cdot \alpha_{\text {buffer }}}$

where $K$ is $\mathrm{pH}$ - and buffer-independent metal-ligand binding constant,

$$
\begin{aligned}
\alpha_{\text {proton }}= & 1+\frac{\left[\mathrm{H}^{+}\right]}{K_{\mathrm{a} 3}}+\frac{\left[\mathrm{H}^{+}\right]^{2}}{K_{\mathrm{a} 3} \cdot K_{\mathrm{a} 2}}+\frac{\left[\mathrm{H}^{+}\right]^{3}}{K_{\mathrm{a} 3} \cdot K_{\mathrm{a} 2} \cdot K_{\mathrm{a} 1}}+\cdots \\
& +\frac{\left[\mathrm{H}^{+}\right]^{n}}{K_{\mathrm{a}(n)} \cdot \ldots \cdot K_{\mathrm{a} 3} \cdot K_{\mathrm{a} 2} \cdot K_{\mathrm{a} 1}}
\end{aligned}
$$

is the function of $\mathrm{pH}$ and $\mathrm{p} K_{\mathrm{a}}$ 's of peptide (n denotes the number of acid dissociation constants),

$$
\alpha_{\text {buffer }}=\frac{K_{C u M E S} \cdot[M E S]}{1+\left[\mathrm{H}^{+}\right] / K_{\mathrm{HMES}}}
$$

Fig. 2 Calorimetric titration isotherms of the binding interaction between $\mathrm{Cu}^{2+}$ and D7 or D9 $\mathrm{M}$ in $20 \mathrm{mM}$ MES buffer of $\mathrm{pH} 6$, at $298.15 \mathrm{~K}$
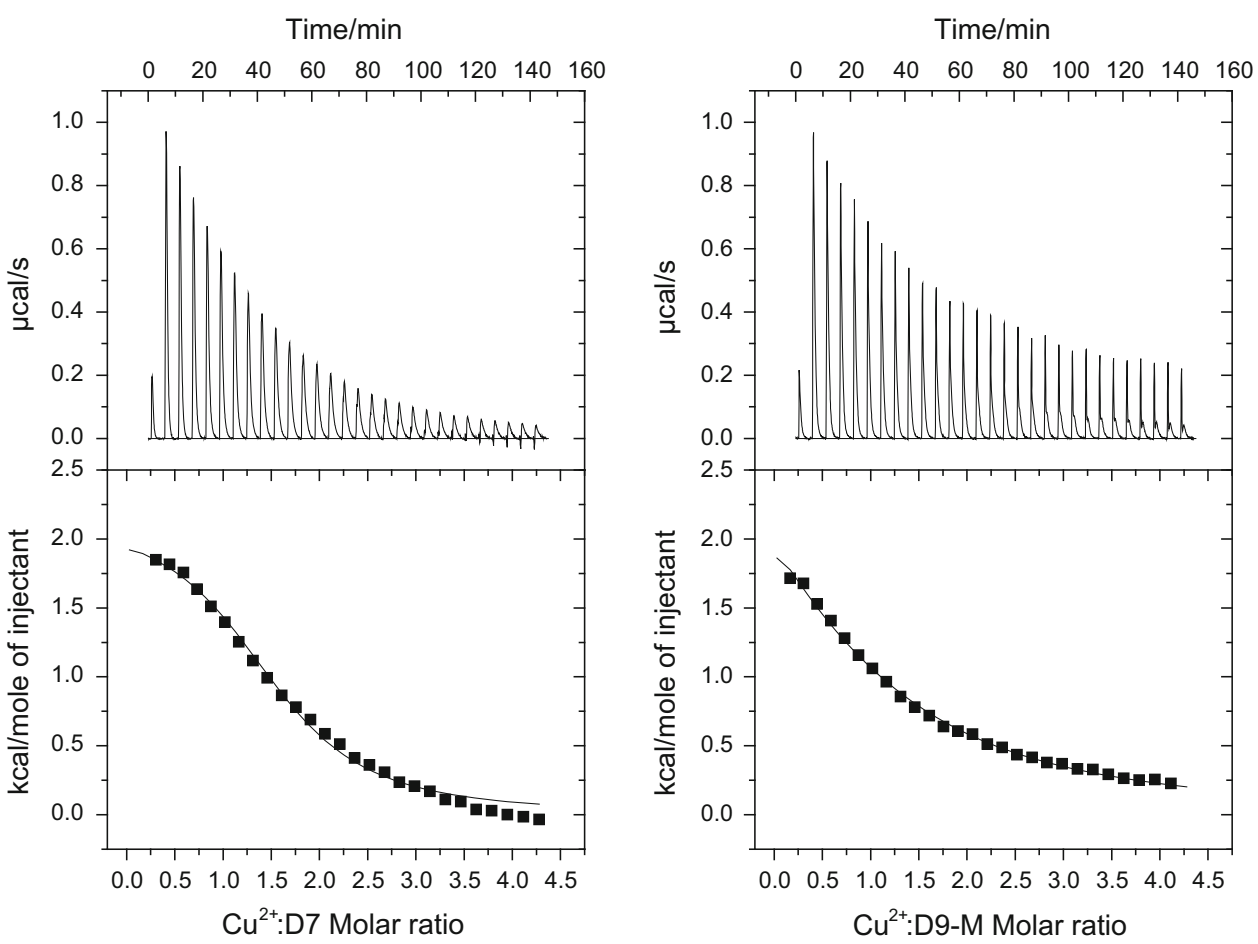
is the function of $\mathrm{pH}$-independent $\mathrm{Cu}-\mathrm{MES}$ binding constant $\left(K_{\text {CuMES }}\right)$, the acid dissociation constant of MES buffer component $\left(K_{\mathrm{MES}}\right)$ and the $\mathrm{pH}-$ dependent concentration of buffer species $\left(\mathrm{HMES}^{ \pm}=\mathrm{H}^{+}+\mathrm{MES}^{-}\right)$involved in the coordination of the copper(II) ion.

The conditional (observed) enthalpy of the $\mathrm{Cu}(\mathrm{II})-$ peptide interaction, measured directly in the ITC experiments, is equal to the sum of all energetic effects corresponding to the particular equilibrium taking place for the complexation process (Table 2).

The overall reaction for the formation of $\mathrm{Cu}(\mathrm{II})$-peptide complex in the presence of buffer substances (MES) in the system is given by the general Eq. (2):

$$
\begin{aligned}
(\mathrm{x} & \left.-\alpha_{\text {CuMES }}\right) \mathrm{Cu}+\alpha_{\text {CuMES }} \text { CuMES } \\
& +\left(\mathrm{x}-\mathrm{y} \alpha_{\text {Hpeptide }}-\mathrm{y} \alpha_{\mathrm{H} 2 \text { peptide }}-\mathrm{y} \alpha_{\mathrm{H} 3 \text { peptide }}\right. \\
& \left.-\cdots-\mathrm{y} \alpha_{\text {Hnpeptide }}\right) \text { peptide } \\
& +\left(\mathrm{y} \alpha_{\text {Hpeptide }}\right) \mathrm{H} \text { Hpeptide }+\left(\mathrm{y} \alpha_{\mathrm{H} 2 \text { peptide }}\right) \mathrm{H}_{2} \text { peptide } \\
& +\left(\mathrm{y} \alpha_{\mathrm{H} 3 \text { peptide }}\right) \mathrm{H}_{3} \text { peptide }+\cdots+\left(\mathrm{y} \alpha_{\text {Hnpeptide }}\right) \text { Hnpeptide } \\
& +\left(\mathrm{y} \alpha_{\text {Hpeptide }}+2 \mathrm{y} \alpha_{\mathrm{H} 2 \text { peptide }}+3 \mathrm{y} \alpha_{\mathrm{H} 3 \text { peptide }}\right. \\
& \left.+\cdots+\text { ny } \alpha_{\mathrm{Hnpeptide}}\right) \mathrm{MES}=\mathrm{Cu}_{\mathrm{x}}(\text { peptide }) \mathrm{y} \\
& +\left(\mathrm{y} \alpha_{\mathrm{Hpeptide}}+2 \mathrm{y} \alpha_{\mathrm{H} 2 \text { peptide }}+3 \mathrm{y} \alpha_{\mathrm{H} 3 \text { peptide }}\right. \\
& \left.+\cdots+\text { ny } \alpha_{\text {Hnpeptide }}\right) \text { HMES }
\end{aligned}
$$

Taking into account the fact that the heat absorbed or released during ITC experiments is equal to the sum of all the energetic effects corresponding to the particular equilibria taking place for complexation process (Table 2), the $\mathrm{pH}$ and buffer-independent enthalpy of the $\mathrm{Cu}^{2+}$-peptide interaction $\left(\Delta_{\text {Cux(peptide) } y} H^{\circ}\right)$ can be calculated from the equation based on Hess's law (Eq. 3).

$$
\begin{aligned}
\Delta_{\mathrm{ITC}} H= & -\alpha_{\mathrm{CuMES}} \cdot x \cdot \Delta_{\mathrm{CuMES}} H^{\circ}-\alpha_{\mathrm{Hpeptide}} \cdot y \cdot \Delta_{\mathrm{Hpeptide}} H^{\circ} \\
& -\alpha_{\mathrm{H} 2 \text { peptide }} \cdot y \cdot \Delta_{\mathrm{H} 2 \text { peptide }} H^{\circ} \\
& -\alpha_{\mathrm{H} 3 \text { peptide }} \cdot y \cdot \Delta_{\mathrm{H} 3 \text { peptide }} H^{\circ} \\
& +\left(\alpha_{\mathrm{Hpeptide}}+2 \alpha_{\mathrm{H} 2 \text { peptide }}+3 \alpha_{\mathrm{H} 3 \text { peptide }}\right. \\
& \left.+\cdots+\text { n } \alpha_{\mathrm{H} 3 \text { peptide }}\right) \Delta_{\mathrm{HMES}} H \\
& +\Delta_{\text {Cux }(\text { peptide }) y} H^{\circ}
\end{aligned}
$$

Thus, in order to determine the $\mathrm{pH}$-independent and bufferindependent parameters of the $\mathrm{Cu}^{2+}$-peptide interaction, the values of $\Delta_{\mathrm{H} n \text { (peptide) }} H^{\circ}, \Delta_{\mathrm{CuMES}} H^{\circ}$ and $K_{\mathrm{CuMES}}$ should be known.

Our preliminary study shows that the D7 peptide is more flexible then the D9 M peptide. Probably, fast changes in the conformation of the more flexible peptide are conducive for binding metal ions, which is in good agreement with the results

\begin{tabular}{|c|c|c|}
\hline Reaction $^{\mathrm{a}}$ & Coefficient $^{\mathrm{b}}$ & $\Delta H^{\mathrm{c}}$ \\
\hline $\mathrm{xCuMES}=\mathrm{xCu}+\mathrm{xMES}$ & $\begin{array}{l}\alpha_{\text {CUMES }}=\frac{K_{\text {CMMES }}^{\prime}[\mathrm{MES}]}{1+K_{\text {CuMES }}^{\prime}[\mathrm{MES}]} \\
\left(K_{\text {CuMES }}^{\prime}=\frac{K_{\text {CuMES }}}{1+\left[\mathrm{H}^{+}\right] / K_{\text {HMES }}}\right)\end{array}$ & $-\mathrm{x} \cdot \Delta_{\mathrm{CuMES}} H^{\circ}$ \\
\hline $\mathrm{yH}($ peptide $)=\mathrm{y}($ peptide $)+\mathrm{yH}$ & $\alpha_{\text {Hpeptide }}=\frac{\left[\mathrm{H}_{3} \mathrm{O}^{+}\right]}{K_{\mathrm{a} 3} \cdot \alpha_{\text {proton }}}$ & $-\mathrm{y} \cdot \Delta_{\mathrm{H}(\text { peptide })} H^{\circ}$ \\
\hline $\mathrm{yH}_{2}($ peptide $)=\mathrm{y}($ peptide $)+2 \mathrm{yH}$ & $\alpha_{\mathrm{H} 2 \text { peptide }}=\frac{\left[\mathrm{H}_{3} \mathrm{O}^{+}\right]^{2}}{K_{23} \cdot K_{\mathrm{a} 2} \cdot \alpha_{\text {proton }}}$ & $-\mathrm{y} \cdot \Delta_{\mathrm{H} 2 \text { (peptide) }} H^{\circ}$ \\
\hline $\mathrm{yH}_{3}($ peptide $)=\mathrm{y}($ peptide $)+3 \mathrm{yH}$ & $\alpha_{\mathrm{H} 3 \text { peptide }}=\frac{\left[\mathrm{H}_{3} \mathrm{O}^{+}{ }^{3}\right.}{K_{\mathrm{K}_{3}} \cdot \mathrm{K}_{\mathrm{a}} \cdot \mathrm{K}_{\mathrm{Ka}} \cdot \cdot_{\text {ppoton }}}$ & $-\mathrm{y} \cdot \Delta_{\mathrm{H} 3(\text { peptide })} H^{\circ}$ \\
\hline $\mathrm{yH}_{\mathrm{n}}($ peptide $)=\mathrm{y}($ peptide $)+\mathrm{n} \cdot \mathrm{yH}$ & $\alpha_{\mathrm{H} 3 \mathrm{NTA}}=\frac{\left[\mathrm{H}_{3} \mathrm{O}^{+}\right]^{3}}{K_{\mathrm{a} 3} \cdot K_{\mathrm{a} 2} \cdot K_{\mathrm{a}} 1 \cdot \alpha_{\text {proton }}}$ & ${ }^{\cdots} \mathrm{y} \cdot \Delta_{\mathrm{H} n(\text { peptide) }} H^{\circ}$ \\
\hline $\begin{array}{l}\mathrm{xCu}+\mathrm{y} \text { peptide }=\mathrm{Cu}_{\mathrm{x}}(\text { peptide })_{\mathrm{y}} \\
\mathrm{MES}+\mathrm{H}=\text { HMES }\end{array}$ & $\begin{array}{l}1 \\
y \alpha_{\mathrm{Hpeptide}}+2 y \cdot \alpha_{\mathrm{H} 2 \text { peptide }}+3 \mathrm{y} \cdot \alpha_{\mathrm{H} 3 \text { peptide }}+\cdots+n \mathrm{y} \cdot \alpha_{\mathrm{H} n \text { peptide }}\end{array}$ & $\begin{array}{l}\Delta_{\text {Cur(peptide) })} H^{\circ} \\
\Delta_{\text {HMES }} H^{\circ}\end{array}$ \\
\hline
\end{tabular}
of the ITC experiment. The complex system of the D7 peptide and $\mathrm{Cu}^{2+}$ ions $\left(\mathrm{Cu}^{2+}-\mathrm{D} 7\right)$ has a higher thermal stability in comparison with the pure D7 peptide (for both systems, the $\mathrm{T}_{\mathrm{m}} \mathrm{s}$ was determined from the heat capacity curves, see Fig. 3; the experimental curves are indicated by black lines, and the fitted to the two-state model curves are indicated by red lines). The DSC measurements show that $\mathrm{Cu}^{2+}$ ions stabilize a new conformation of the D7- $\mathrm{Cu}^{2+}$ complex. For the D9 M peptide, the presence of a large number amino acid residue with expanded side chains in this longer sequence induces a more fixed and dominating conformation, in comparison with the $\mathrm{D} 7$ peptide. The DSC experiment suggests that interactions between the

Table 2 Individual reactions that contribute to the overall equilibrium for the formation of $\mathrm{Cu}(\mathrm{II})$-peptide complex in the MES buffer solution (the charges of ions are omitted for the sake of clarity)

\footnotetext{
${ }^{a}$ Equilibria are written in the direction that the reaction

b The coefficients indicate the percentage of particular species in the solution under experimental conditions

c $\Delta H^{\circ} / \mathrm{kcal} \mathrm{mol}^{-1}$ values are for the association reactions
} 
Fig. 3 Heat capacity curves of D7, D7- $\mathrm{Cu}^{2+}$, D9 $\mathrm{M}$ and D9 $\mathrm{M}-\mathrm{Cu}^{2+}$ peptides determined by DSC (the experimental curve; black line) and the fit to the two-state model (the theoretical curve; red line). (Color figure online)
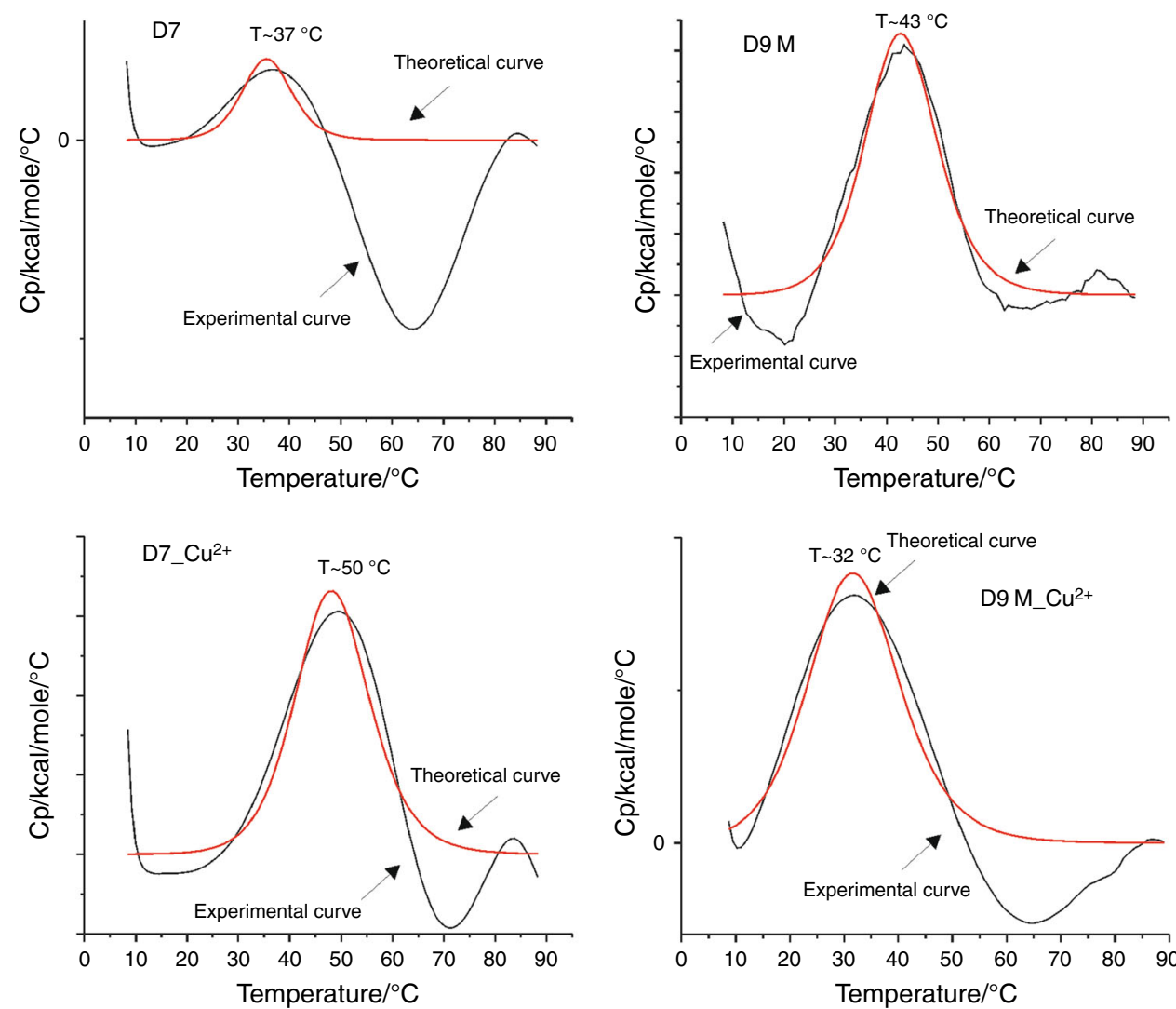

D9 $\mathrm{M}$ peptide and $\mathrm{Cu}^{2+}$ ions force conformational changes that destabilize the thermal stability of the formed conformation for the $\mathrm{Cu}^{2+}-\mathrm{D} 9 \mathrm{M}$ system (Fig. 3). This presumption confirms both a lower value of the stability constant and the lower stoichiometry of the newly formed $\mathrm{Cu}^{2+}-\mathrm{D} 9 \mathrm{M}$ complex. It has been shown that probably, the higher flexibility of the ligand is more favorable in the binding reactions between peptides and metal ions. Additionally, the DSC measurements show that the $\mathrm{D} 7$ peptide has a big tendency to aggregate over $\sim 40{ }^{\circ} \mathrm{C}$. The heat capacity curve of the complex system of the D7 peptide and $\mathrm{Cu}^{2+}$ ions shows that interactions between the D7 peptide and $\mathrm{Cu}^{2+}$ decrease such tendency. The D9 $\mathrm{M}$ and D9 $\mathrm{M}-\mathrm{Cu}^{2+}$ complex do not have tendency for aggregation. However, it should be noted that for all systems a low height and broad shape of the peaks suggest that a dynamic equilibrium between interconverting conformations is established. The heat capacity curves have a broad maximum region, and it can, therefore, be concluded that the D7 and D9 M peptides and their complexes occur as a mixture of interconverting conformations in a dynamic equilibrium.

\section{Conclusions}

Based on the results of isothermal titration calorimetry, conditional thermodynamic parameters $\left(\Delta_{\text {ITC }} G, \Delta_{\text {ITC }} H\right.$ and $\Delta_{\text {ITC }} S$ ) have been determined for the complexation reaction of
$\mathrm{Cu}^{2+}$ ions with Ac-Lys-Thr-Ala-Asp-Gly-Lys-Thr-NH (D7) $^{2}$ and Ac-Tyr-Lys-Thr-Ala-Asn-Gly-Lys-Thr-Tyr- $\mathrm{NH}_{2}$ (D9 M), as well as the stoichiometry of the resulting complexes and their conditional stability constants (in $20 \mathrm{mM}$ MES buffered solution with a $\mathrm{pH}$ of 6 , at $298.15 \mathrm{~K}$ ). At the conditions under study, the D7 and D9 M peptides act as relatively weak ligands; however, the stability of the complex with the former ligand is ca. one order higher than for the latter. Moreover, it has been found that the binding enthalpies of the resulting copper(II)-peptide complexes are positive $\left(\Delta_{\mathrm{Cu} \text { (D7)2 }}\right.$ $H=+2.18 \quad( \pm 0.07)$ and $\Delta_{\mathrm{CuD} 9 \mathrm{M}} H=+4.36 \quad( \pm 0.40)$ $\mathrm{kcal} \mathrm{mol}^{-1}$ ); hence, the processes under study are entropydriven. The $\Delta_{\mathrm{CuD9M}} H$ is two times higher that $\Delta_{\mathrm{Cu}(\mathrm{D} 7) 2} H$. As the obtained enthalpies of reaction are conditional parameters, the difference in their values is mainly due to the different stoichiometry of the copper(II) complexes (Cu:D7 = 3:2 and Cu:D9 $M=1: 1$ ), different ionization enthalpy of the peptides, as well as different distributions of species capable of the release (or uptake) of protons.

The DSC results showed that the stoichiometry of the metal-ligand interactions and the value of their binding constants $\left(K_{\text {ITC }}\right)$ has the ability to induce significant conformational changes. Probably, for the more flexible ligand, the newly formed complex (i.e., $\mathrm{Cu}^{2+}-\mathrm{D} 7$ ) is more thermodynamically stable. For peptides with a more fixed and dominating conformation, $\mathrm{Cu}^{2+}$ metal ions destabilize the newly formed structures (i.e., $\mathrm{Cu}^{2+}-\mathrm{D} 9 \mathrm{M}$ ). 
The ITC method is a useful tool for investigating metalligand interactions in solution. However, as far as the interaction of metal ions and peptide is concerned, the determination of condition-independent thermodynamic parameters that can be compared to values obtained by other experimental methods is not always easy. The most important factors that have an impact on the obtained conditional parameters are the enthalpy of proton-peptide dissociation, the enthalpy of the $\mathrm{Cu}-\mathrm{MES}$ interaction and the copper(II)-MES affinity $\left(K_{\text {CuMES }}\right)$. Despite the fact that, as far as we are concerned, the above parameters are not yet available in the literature, we have described in this paper a data analysis method that includes the effect of buffer competition with the peptide for the metal, as well as proton competition with the metal for the peptide and the buffer's component. The presented procedure can be adopted for different experimental conditions ( $\mathrm{pH}$, the metal ions and the buffer type).

Acknowledgements This work was supported by a grant from the Polish National Science Centre (NCN 2011/01/D/ST4/04497) and BMN 2014 nr 538-8232-B344-14.

Open Access This article is distributed under the terms of the Creative Commons Attribution License which permits any use, distribution, and reproduction in any medium, provided the original author(s) and the source are credited.

\section{References}

1. Scheinberg H. Wilson's disease and the physiological chemistry of copper. Inorganic chemistry in biology and medicine. ACS Symp Ser. 1980;140:373-80.

2. Crisponi G, Nurchi VM, Fanni D, Gerosa C, Nemolato S, Faa G. Copper-related diseases: from chemistry to molecular pathology. Coord Chem Rev. 2010;254:876-89.

3. Laurie SH, Lund T, Raynor JB. Electronic absorption and electron spin resonance studies on the interaction between the biologically relevant copper(II) glycylglycine and L-histidine complexes with D-penicillamine. J Chem Soc, Dalton Trans. 1975;14:1389-94.
4. Belosi B, Gaggelli E, Guerrini R, Kozłowski H, Łuczkowski M, Mancini FM, Remelli M, Valensin D, Valensin G. Copper binding to the neurotoxic peptide PrP106-126: thermodynamic and structural studies. ChemBioChem. 2004;5:349-59.

5. Remelli M, Donatoni M, Guerrini R, Janicka A, Pretegiani P, Kozłowski H. Copper-ion interaction with the 106-113 domain of the prion protein: a solution-equilibria study on model peptides. Dalton Trans. 2005; 17:2876-85.

6. Kozłowski H, Janicka-Kłos A, Stańczak P, Valensin D, Valensin $\mathrm{G}$, Kulon K. Specificity in the $\mathrm{Cu} 2+$ interactions with prion protein fragments and related His-rich peptides from mammals to fishes'. Coord Chem Rev. 2008;252:1069-78.

7. Gumienna-Kontecka E, Nurchi VM, Szebesczyk A, Bilska P, Krzywoszynska K, Kozlowski H. Chelating agents as tools for the treatment of metal overload. Z Annorg Allg Chem. 2013;639:1321-31.

8. Skwierawska A, Makowska J, Ołdziej S, Liwo A, Scheraga HA. Mechanism of formation of the C-terminal $\beta$-hairpin of the B3 domain of the immunoglobulin binding protein $\mathrm{G}$ from Streptococcus I Importance of hydrophobic interactions in stabilization of $\beta$-hairpin structure. Proteins: Struct, Funct, Bioinf. 2009;75:931-53.

9. Makowska J, Żmudzińska W, Uber D, Chmurzyński L. NMR study of the influence of charged residues on $\beta$-hairpin formation. Protein J. 2014;33:525-35.

10. Makowska J, Uber D, Chmurzyński L. Thermodynamics of protonation equilibria of two fragments of $\mathrm{N}$-terminal $\beta$-hairpin of FPB28 WW domain. J Phys Chem B. 2012;116:653-9.

11. Makowska J, Baginska K, Skwierawska A, Liwo A, Chmurzynski L, Scheraga HA. Influence of charge and size of terminal aminoacid residues on local conformational states and shape of alaninebased peptides. Biopolymers. 2008;90:772-82.

12. Wyrzykowski D, Zarzeczańska D, Jacewicz D, Chmurzyński L. Investigation of copper(II) complexation by glycylglycine using isothermal titration calorimetry. J Therm Anal Calorim. 2011;105:1043-7.

13. Wyrzykowski D, Pilarski B, Jacewicz D, Chmurzyński L. Investigation of metal-buffer interactions using isothermal titration calorimetry. J Therm Anal Calorim. 2013;111:1829-36.

14. Plotnikov V, Rochalski A, Brandts M, Brandts JF, Williston S, Frasca V, Lin LN. An autosampling differential scanning calorimeter instrument for studying molecular interactions. Assay Drug Dev Technol. 2002;1:83-90. 